\title{
Relationships between the Determinants of Sustainable Performance and Employee Motivation: A Structural Equation Model
}

\author{
Aurelio Tommasetti ${ }^{1}$, Valerio Antonelli², Raffaele D'Alessio ${ }^{1}$, Carlo Torre ${ }^{1}$ \\ ${ }^{1}$ Business Administration, University of Salerno, Fisciano, Italy \\ ${ }^{2}$ Audit University of Salerno, Fisciano, Italy \\ Email: rettore@unisa.it,vantonelli@unisa.it,ctorre@unisa.it
}

How to cite this paper: Tommasetti, A., Antonelli, V., D'Alessio, R. and Torre, C. (2019) Relationships between the Determinants of Sustainable Performance and Employee Motivation: A Structural Equation Model. Journal of Service Science and Management, 12, 58-76.

https://doi.org/10.4236/jssm.2019.121004

Received: September 28, 2018

Accepted: January 14, 2019

Published: January 17, 2019

Copyright $\odot 2019$ by author(s) and Scientific Research Publishing Inc. This work is licensed under the Creative Commons Attribution International License (CC BY 4.0).

http://creativecommons.org/licenses/by/4.0/

(C) (i) Open Access

\begin{abstract}
The work, in fact, starting from the study conducted by some scholars, aims to understand how the strategic decisions of the company management affect the company's performance and, ultimately, the motivation of the employees. More specifically, the paper seeks to measure, if and how, sustainable management, the prospectors' strategy and the reactors affect organizational and sustainable performance, ultimately impacting on the motivation of the employees of the Municipalities that make up the sample of the analysis. The methodology used to measure the link between the variables considered is represented by structural equation models, which allow measuring simultaneously the relationships existing between two and more variables. The sample analysis is composed of the employees of some municipalities of the Amalfi Coast (Amalfi, Ravello, Positano and Maiori...) to whom questions have been asked to measure their perception regarding the variables of the proposed theoretical model. The results of the paper confirm the validity and reliability of the measurement scales adopted, since both the Bartlett test and the Kayser-Meyer-Olkin sample adequacy test (KMO) indicate that the factor analysis it is adequate to the sample used. Furthermore, the paper also allows confirming the theoretical hypotheses proposed, showing how work is a useful tool for both practioners and scholars.
\end{abstract}

\section{Keywords}

Employee Motivation, Structural Equation Model, Sustainable Management, Performance 


\section{Introduction}

Most of the studies on social and environmental reporting have focused more on private sector companies, rather than on the public sector.

However, in recent times, especially at the international level, there has been growing concern about the social impacts generated by the activities of public organizations. In this regard, the inability of the traditional financial reporting systems to adequately measure the social and environmental impacts of performance, has led several scholars [1] to deepen the study of social and environmental organizational performance, investigating the predictive capacity of the relationship between sustainable management and performance.

Prior literature on the relationship between sustainable management and performance shows how the positive effects of social responsibility practices are closely linked to a series of performance dimensions [2]. In fact, on this trail, several scholars underlined how the adoption of specific social, economic and environmental actions has a positive impact on performance, moderating the negative impact of the actions implemented by the organizations [3].

The analysis of the performances of the companies and of the organizations pushes, therefore, with increasing vigor, towards the consideration of aspects related to social responsibility, including in the organizational action measures such as pollution control, waste management, dissemination of social performance and compliance with pre-established standards of conduct [4]. These measures are aimed at evaluating actions and performances that generate a significant impact in different fields of life.

The search for a sustainable development of the different territorial areas passes through an integrated management of the services offered by public organizations. However, the pursuit of integrated management processes is, in turn, a function of the creation of real service ecosystems, in which the various social actors coexist in a sustainable way [5].

Following this logical approach, the most recent research on the performance of public and non-profit organizations, it was proposed to examine the link between sustainable performance, formal effectiveness and efficiency [6]. In order to respond to this purpose, this paper seeks to relate the concept of sustainable management with that of performance, understood in the twofold sense of organizational performance and sustainable performance.

The objective of the paper is, in fact, to examine how higher levels of performance are able to positively impact on employee motivation.

The methodology used to measure the link between the variables considered is represented by structural equation models, which allow measuring simultaneously the relationships existing between two and more variables. The sample analyzed is composed of the employees of some municipalities of the Amalfi Coast (Amalfi, Ravello, Positano and Maiori...) to whom questions have been asked to measure their perception regarding the variables of the proposed theoretical model. 
The work, in fact, starting from the study conducted by some scholars, aims to understand how the strategic decisions of the company management affect the company's performance and, ultimately, the motivation of the employees [7]. More specifically, the paper seeks to measure, if and how, sustainable management, the prospectors' strategy and the reactors affect organizational and sustainable performance, ultimately impacting on the motivation of the employees of the Municipalities that make up the sample of the analysis. The remaining part of the paper consists of three sections. The first describes the theoretical hypotheses supporting the model being analyzed.

The second describes the methodology used and the sample object of the analysis, while in the third part the results of the analysis, the discussions and the conclusions are presented.

\section{Prior Literature}

The aim of the work is to analyze the relationships between Sustainable Management, Prospector Strategy, Reactors Strategy and Organizational and Sustainable Performance, looking, secondly, to study, if and how, the latter variable is able to exert an influence positive on employee motivation. This objective is pursued through the use of a model of structural equations, capable of simultaneously measuring the reciprocal influence between the variables mentioned and depicted in Figure 1. The analysis technique adopted, therefore, allowed to test the theoretical hypotheses derived from previous studies.

\subsection{Sustainable Management}

Current economic-social context, increasingly interested in achieving better business returns, drives companies and organizations to create dense networks of relationships. Relational network of each company allows, in fact, to generate

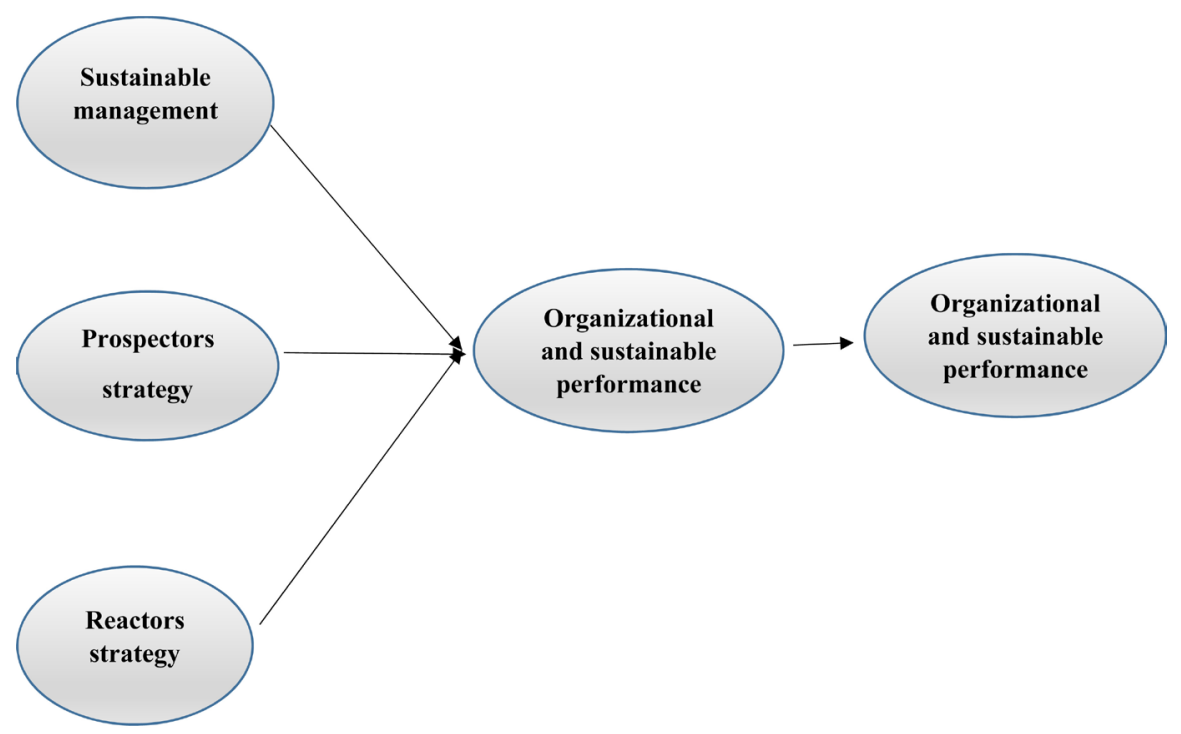

Figure 1. Theoretical model. Source: Author's elaboration. 
sustainable wealth in the long run, expanding the chances of survival of organizations [8]. In recent years there have been several attempts to revise traditional reporting methods. In particular, the turnaround towards reporting tools such as social and environmental reports, as well as the GRI sustainability reports (GRI, 2006) shows a willingness to review the methods of communication and information useful for decision-making processes of companies [9]. This new way of understanding business life has led to a rethinking of the nature and structure of corporate goals. Following this, the elements able to determine the success of the company's efforts were reviewed, highlighting the role played, not only by the expectations of shareholders, but also those deriving from all the other stakeholders [10].

Given the turbulence and complexity of the context in which they operate, companies have begun to reconsider traditional performance measurement systems in order to respond to stakeholders' needs effectively, communicating and reporting on the results achieved.

The new evaluation and communication systems have, in fact, the objective of expanding, integrating and improving the company system. Based on these considerations it is therefore possible to hypothesize that:

H1: sustainable management practices have a positive impact on organizational and sustainable performance.

\subsection{Prospectors Strategy}

In literature there are discordant visions regarding the effectiveness of the different ways of providing public services. It seems, however, clear that the effect of the organizational structure on performance results, more often than not, mediated by other organizational factors. In this regard, some scholars, argue that the effectiveness of the organizational structure can be maximized by developing appropriate connections between the different internal management systems [11]. The existence of adequate links between corporate strategies and organizational characteristics of companies and organizations is therefore considered an indispensable condition for improving company performance [12]. Along these lines, several studies show how the strategic choices capable of increasing the potential of companies are characterized by various structural configurations. Among these, a prominent role plays the prospectors strategy [13]. Companies that base their actions on the prospectors strategy almost constantly seek market opportunities, experimenting with potential responses to emerging environmental trends. In this way, these organizations stimulate the situations of change and uncertainty to which the competitors must respond. However, due to their strong preoccupation with product and market innovation, these organizations are usually not completely efficient [14]. Some scholars on this point show how the strategic choices adopted by companies influence their performance [15]. In fact, a company generally chooses the company strategy based on its understanding of the environment. In the same way, the strategy adopted is 
able to direct the company's attention to certain dimensions of performance, increasing its effectiveness [16]. Thus, market-oriented companies are more able to identify and share relevant information, and succeed in making more informed and effective decisions. These considerations therefore allow us to hypothesize that:

$\mathrm{H} 2$ : the prospectors strategy have a positive impact on the organizational and sustainable performance of companies.

\subsection{Reactors Strategy}

Several studies have shown how the organizations that base their mission on the prospectors strategy aim to reach new and emerging market opportunities [17]. On the other hand, organizations that adopt the so-called reactors strategy try to strengthen previously acquired positions, pursuing the consolidation of the gains obtained [18]. In this regard, there are several empirical evidence able to show how the public organizations that adopt these strategies are mainly oriented to the efficiency of business processes [19].

The reactors, in fact, relying mainly on the pressures deriving from the surrounding environment, do not imply the existence of a substantial strategy, limiting themselves, most of the time, to incorporating the impositions of the legislator [20].

Also with reference to private sector companies there is empirical evidence that suggests that the overall strategy of companies and organizations is able to impact on company performance [21]. In fact, strategic choices based on innovation are very often associated with higher performances [22]. In fact, some studies argue that both public and private organizations that base their activity on innovation are better able to achieve successful environmental performance [23]. Otherwise, those companies that base their activity on defensive strategies, remaining only in compliance with certain prescriptions, are less performing [24]. Based on these considerations, it is therefore possible to hypothesize that:

H3: the reactors strategy, unlike the proactors strategy, negatively impact on organizational and sustainable performance.

\subsection{Organizational and Sustainable Performance}

Several studies have shown that investing in social responsibility allows companies to increase the level of employee involvement, motivating them to open up to the outside world and feel an integral part of company [25]. In this regard, other scholars stressed that it is necessary, in order to maximize the benefits deriving from the social commitment of companies, the involvement of employees in the decision-making process [26].

In fact, the greater the importance that employees attach to CSR's actions, the greater their degree of involvement in company management will be. As a result, employee involvement, helping to improve their performance, ultimately exerts a positive influence on company performance [27]. The sustainable practices 
adopted by companies, allowing the activation of managerial mechanisms aimed at strengthening management viability, lead to greater economic, social and environmental performance.

The formulation of sustainable strategies implies the involvement of different organizational functions, increasing the importance of the role played by human resources in the processes of generating value. In this vein, has been argued that the realization of sustainable performance represents a fundamental element to increase the quality and motivation of company employees [28].

In fact, the human resources management (HRM), understood as the organizational area that has the greatest potential for integrating sustainability issues, is able to contribute profitably to the pursuit of sustainable organizational performance [29].

These considerations are reflected in the arguments of other scholars, according to which the pursuit of sustainable performance allows to increase the centrality of employees for the success of companies [30]. As a result, the awareness of playing a fundamental role in corporate survival makes employees increasingly motivated and involved in company processes [31].

These considerations allow to hypothesize that:

H4: organizational and sustainable performance exert a positive impact on employee motivation.

\section{Data Description}

The data of the study were collected through the administration of a questionnaire to the employees of some municipalities of the Province of Salerno. However, in order to verify the clarity and comprehensibility of the questions formulated, before proceeding with the administration, the questionnaire was subjected to a small sample of employees met randomly near the Municipalities involved in the study.

The pretest allowed, in fact, to make changes to some statements, allowing to succeed the final version. Participation in the study was voluntary and the respondents were assured that the data were treated in a reserved manner. 325 questionnaires were actually distributed, of which 265 were collected. Of these 265,15 were rejected because they presented incomplete answers and others able to generate relevant problems in terms of response sets.

As shown in Table 1, of the employees interviewed, 53.20\% were males and $46.80 \%$ were females.

The age ranged between 25 and 65 with an average of 52.5 years. Employees residing in the municipalities of the province of Salerno were interviewed, in particular those of Amalfi, Ravello, Scala, Atrani, Conca de Marini, Maiori.

All constructs that make up the model were measured using multiple indicators adapted from previous studies. In particular, the scale of items proposed by Menguc and Ozanne [32]); Chen and Paulraj [32]; Zhu, Sarkis and Lai [33]; Min and Galle [34]; Zhu and Geng (2001) [35]; Zhu and Sarkis (2004) [36] was revived 
Table 1. Composition of the sample being analyzed.

\begin{tabular}{cccc}
\hline Number of respondents & Total & Men & Women \\
\hline Geographical origin & 250 & $133(53.20 \%)$ & $117(46.80 \%)$ \\
Amalfi & & & \\
Ravello & $40(16 \%)$ & $25(62.50 \%)$ & $15(37.50 \%)$ \\
Castel San Giorgio & $30(12 \%)$ & $17(56.67 \%)$ & $13(43.33 \%)$ \\
Maiori & $45(18 \%)$ & $20(44.44 \%)$ & $25(55.56 \%)$ \\
Fisciano & $50(20 \%)$ & $30(60 \%)$ & $20(40 \%)$ \\
Siano & $50(20 \%)$ & $22(44 \%)$ & $28(56 \%)$ \\
Minori & $15(6 \%)$ & $6(40 \%)$ & $9(60 \%)$ \\
Other Geographical (SA) & $10(4 \%)$ & $5(50 \%)$ & $5(50 \%)$ \\
\hline
\end{tabular}

Source: author's elaboration.

for sustainable management; for the prospectors strategy they were adapted by Boyne and Walker (2004) [21] 4 items; for the reactors strategy 4 items were adapted by Burton \& Turner [37]; Boyne \& Walker [38], while the 8-item scale originally proposed by Zhu and Sarkis [36], Menguc and Ozanne [32] e Bansal [39] was used for the organizational and sustainable performance and, lastly, by Van Breukelen, Van der Vlist, \& Steensma [40]; Porter, Steers, Mowday, \& Boulean [41] have been adapted the 7 items for the measurement of the "employee's motivation". As suggested by Bastian et al. [42], all variables were measured using a 5-point Likert scale ranging from 1 (strongly disagree) to 5 (strongly agree).

\section{Results}

Consistent with the indications provided by some scholars, we proceeded to identify the factors that best explain the selected constructs, carrying out an analysis of the main components [43]. Subsequently, as suggested by Jolliffe [44], the reliability of each measurement scale resulting from the ACP was verified.

The verification of the validity and reliability of the scales, as indicated in Table 2, resulted in an iterative process which, at the end, provided all the values able to satisfy the minimum thresholds of acceptability, with regard to the KMO Test (>0.5, Hair et al. [45]), at the spherical test of Bartlett (Sign. $<0.005$, Tabachnick e Fidell [46]), to the explained variance of the phenomenon analyzed ( $>0.50$, Pett et al. [47]; Hair et al. [45]) and Cronbach's Alpha ( $>0.70$, Capelli et al. [48]):

The data contained in the Table 3 therefore seem to confirm the validity and reliability of the measurement scales adopted, since both the Bartlett test and the Kayser-Meyer-Olkin sample adequacy test (KMO) indicate that the factor analysis it is adequate to the sample used.

These two tests, in fact, make it possible to evaluate the applicability of the 
Table 2. Validity of the measurement scales.

\begin{tabular}{cccc}
\hline \multirow{2}{*}{ Variables } & \multicolumn{3}{c}{ VALIDITY OF THE SCALES } \\
\cline { 2 - 4 } & Test KMO & $\begin{array}{c}\text { Test di Bartlett } \\
\text { (Sign.) }\end{array}$ & $\begin{array}{c}\text { Varianza totale } \\
\text { spiegata }\end{array}$ \\
\hline Sustainable management & 0.931 & 0.000 & 80.981 \\
Prospectors strategy & 0.726 & 0.000 & 65.611 \\
Reactors strategy & 0.819 & 0.000 & 79.652 \\
Organizational and sustainable performance & 0.925 & 0.000 & 74.867 \\
Employee motivation & 0.886 & 0.000 & 71.846 \\
\hline
\end{tabular}

Source: authors' elaboration.

Table 3. Reliability of the measurement scales.

\begin{tabular}{cc}
\hline Variables & RELIABILITY OF THE SCALES \\
\cline { 2 - 2 } & Alpha di Cronbach \\
\hline Sustainable management & 0.950 \\
Prospectors strategy & 0.794 \\
Reactors strategy & 0.914 \\
Organizational and sustainable performance & 0.951 \\
Employee motivation & 0.931 \\
\hline
\end{tabular}

Source: authors' elaboration.

chosen methodology with respect to the available data. Through the test of sphericity of Bartlett the null hypothesis of absence of correlation between the variables is verified, while the Kayser-Meyer-Olkin sample adequacy test allows to quantify the degree of interrelations between the variables and to evaluate if the use the factorial analysis is correct.

Finally, in addition to an adequate capacity of the items to explain the investigated phenomena, thanks to explained variance percentages above the threshold of 50, also the degree of internal coherence of each construct seems to be acceptable, since cronbach's alpha values are present higher than the minimum threshold of 70. Subsequently, in order to verify the simultaneous existence of causal relationships among the variables of the model, a model of structural equations was developed.

The Sem represent, in fact, a technique able to allow:

$\checkmark$ The estimation of multiple and interconnected dependency relationships;

$\checkmark$ The representation of concepts not observed in these relationships, together with the possibility of including in the models the measurement errors produced by the estimation process.

To evaluate the goodness of the model's adaptation, it is useful to keep under control the statistical and substantial validity of the estimates, as well as other conditions represented by the convergence of the estimation process, the empirical identification of the model, the statistical significance of the parameters and, 
finally, from the goodness of adaptation to the covariance matrix.

In the present work, the estimation of the models was carried out using the maximum likelihood method, while the chi-square test was used for the evaluation of the goodness of adaptation, which always ends up showing sensitivity to the sample size, orienting, for this reason and very often, towards the adoption and consideration of alternative indices. In fact, consistently with the arguments of $\mathrm{Hu}$ and Bentler [49], they were used alternatively: the RMR (Root Mean Residual), the CFI (Comparative Fit Index), the IFI (incremental Fit Index) and the RMSEA (Root mean square error of approximation). In order to verify the hypoteses proposed and apply the maximum likelihood method, Lisrel was used. Lisrel is a software able to implement a model of structural equations.

Thus, According to $\mathrm{Hu}$ and Bentler [49], values of the CFI and the IFI $>$ of 0.95 are generally indicative of a good adherence of the model, while with reference to the RMR and the RMSEA, instead, values $<0.08$ and 0.06 , respectively, seem to show, in the same way, a good quality of the model [50]. Therefore, in light of these considerations and as indicated in Table 4, the tested model has a good level of adherence to the reality studied, as there are values of the RMSEA of 0.045 and of the CFI equal to 0.96 :

This allows, therefore, to confirm the hypotheses of the model (see Table 5).

The analysis, therefore, allows us to highlight how the construct represented by sustainable management [51] and the prospectors strategy [52] are able to exert a positive influence on the organizational and sustainable performance, while the reactors strategy [38] negatively affects organizational and sustainable performance. Lastly, the study highlights how this last variable positively influences the employee motivation [53].

Figure 2 also shows the intensity of the relationships between the variables included in the model, highlighting the determinants of employee motivation, in accordance with the aims of the research.

Table 4. Absolute and incremental Indices of Fit.

\begin{tabular}{cc} 
Indices of Fit & Values \\
\hline IFI & 0.96 \\
RMSEA $=\sqrt{\frac{\left(X^{2}-\mathrm{d} f\right)}{\mathrm{d} f(N-1)}}$ & 0.045 \\
CFI $=1-\frac{\tau_{k}}{\tau}$ dove $\tau_{k}=\max \left(X_{m}^{2}-\mathrm{d} f_{m}, 0\right) \mathrm{e}$ & 0.96 \\
$\tau_{j}=\max \left(X_{m}^{2}-\mathrm{d} f_{m}, X_{b}^{2}-\mathrm{d} f_{b} 0\right)$ & \\
Quindi, $\operatorname{molto}$ spesso: CFI $=1-\frac{\left(X_{m}^{2}-\mathrm{d} f_{m}\right)}{\left(X_{b}^{2}-\mathrm{d} f\right)_{b}}$ & \\
RMR $=\left[\begin{array}{c}\left.2 \sum_{i} \sum_{j}\left[\frac{(S i j-\sigma i j)^{2}}{k(k+1)}\right]^{1 / 2}\right] \\
X^{2} / \mathrm{d} f\end{array}\right.$ & 0.06
\end{tabular}

Source: authors' elaboration. 
Table 5. The results of the hypotheses tested.

\begin{tabular}{clc}
\hline Ipotheses & \multicolumn{1}{c}{ Description of the hypotheses } & Results \\
\hline H1 & $\begin{array}{l}\text { Sustainable management practices exert a positive and direct } \\
\text { influence on the organizational and sustainable performance }\end{array}$ & Supported \\
H2 & $\begin{array}{l}\text { Prospectors strategy exertsapositiveanddirectinfluenceon the } \\
\text { organizational and sustainable performance }\end{array}$ & Supported \\
H3 & $\begin{array}{l}\text { Reactors strategy exertsa negative influenceon the organizational and } \\
\text { sustainable performance } \\
\text { Organizational and sustainable performance } \\
\text { exertsapositiveanddirectinfluenceon the employee motivation }\end{array}$ & Supported \\
\hline
\end{tabular}

Source: authors' elaboration.

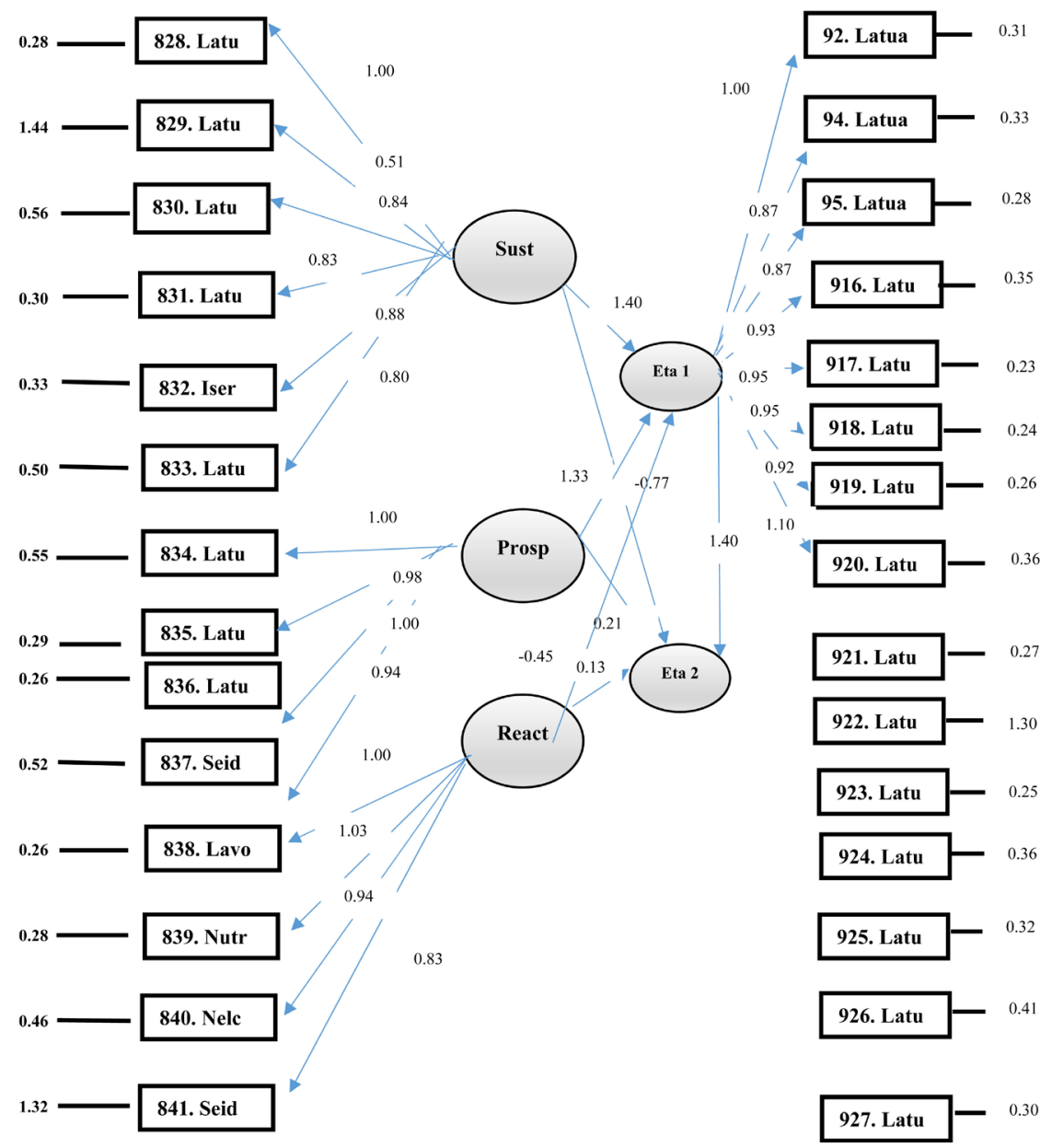

Figure 2. Theoretical model tested. Source: Authors' elaboration.

\section{Discussions}

The study highlights how the growing attention paid by business managers to the assessments made by rating agencies and the general public opinion ends up influencing, in a decisive manner, the company's strategic decisions.

The paper, in highlighting the possible relationships between the company's strategic choices and performance, understood in its triple economic, social and 
environmental dimension, offers an important contribution to scientific studies concerning the analysis of company results [54]. Secondly, the paper pursues the objective of relating company performance to the degree of satisfaction of company employees, starting from the discordant visions that exist in the literature on the subject of human resources management. In this regard, in fact, several scholars [55] consider HRM to be of little influence in influencing employee behavior, while others [56], instead, they consider the relationship between human resources management and company performance much more significant.

The results of the analysis show, in fact, a positive association between company performance and employee satisfaction in work and in everyday life.

The study of the determinants of performance associated with that of employee satisfaction provides an indispensable support to increase the chances of survival of companies and organizations. The ways in which employees respond to HR initiatives depend strictly on performance and organizational results. This suggests that it is important to develop appropriate human resource management practices to achieve quality performance. In fact, the empirical evidence presented show how workers respond positively to the performance of tasks with high added value. In this regard, several scholars [57] have shown that stimulating jobs, involving a broader participation of employees, are associated with a high degree of satisfaction, both in the workplace and in everyday life. The results of the work also show the high impact that corporate strategies have on the performance of companies and organizations. These considerations are consistent with the main intentions of the work, according to which the choices of corporate governance bodies, impacting positively on performance, end up conditioning the level of employee satisfaction.

The influence exerted by the company's strategic choices on performance becomes even more pronounced in a context in which the relationships between the various social actors play a decisive role [58]. In these contexts, in fact, the profitable relationships between those who participate in the processes of value generation, lead to greater competition of each social actor in the pursuit of business purposes, engaging appropriate control mechanisms on the different stages of the value creation process [59]. All this pushes companies, in an attempt to respect the needs of the various social actors, to consider, in their strategic plans, a whole series of aspects related to social responsibility. In this way, the governing bodies of companies and public organizations are inclined to include, in the planning stages of the activities, measures such as pollution control, waste management, disclosure of social performance and compliance to predefined rules of conduct [4].

These measures are aimed at evaluating actions and performances that generate a significant impact in different fields of life, allowing to reach a sustainable development of the different territorial areas

The possibility of achieving a truly sustainable territorial development passes through an integrated management of the services offered by public organiza- 
tions. However, the pursuit of integrated management processes is, in turn, a function of the creation of real service ecosystems, within which the various social actors coexist in a sustainable way [5].

Based on this logical approach, the work allowed to examine the link between strategic decisions, sustainable performance and employee satisfaction of public organizations. In fact, the results of the analysis showed that the employees of some municipalities in the province of Salerno give particular importance to aspects related to environmental sustainability. In fact, the results of the analysis show how, in line with what is suggested by the literature [57], political and administrative choices are able to impact on the ability of local administrations to respond to the needs of the territorial community. In fact, the work has made it possible to highlight how in a territorial area in which the services are offered in an integrated manner, through the synergistic contribution of the various actors involved, the ability to respond to the needs of users is more precise and immediate. This, in turn, allows us to see how the greatest successes of public administrations can translate into a higher degree of satisfaction of those who work within individual organizations [6].

\section{Theoretical Implications}

The work is a useful guide for scholars interested in issues related to the public services sector, in order to have useful information to manage public sector organizations effectively and sustainably.

In fact, from a theoretical point of view, the study contributes to the scientific debate, providing further and new results to support the consideration, according to which, obtaining adequate performances can not be separated from an appropriate management of specific structural conditions.

These structural conditions, acting as useful levers to increase the quality of company performance, determine a real change of perspective in scientific research concerning the management of public sector organizations, directing the latter towards an ever greater consideration of relational aspects and social, capable of transforming the economic perspective of companies from a value perspective to be allocated to all the actors involved in the process of value generation.

The study, in fact, showing the positive effects of the commitment of public organizations in the social and environmental sphere on the results achieved, allows to direct future research towards a deeper study of the factors able to stimulate the sustainable growth of local communities.

In the same way, further empirical evidence regarding the adoption of appropriate strategic choices, push the focus of scientific research towards the consideration of factors more intimately connected to the planning of organizational activities. This leads, therefore, to the need to focus future scientific efforts on the control of factors potentially capable of increasing the quality of the results of public organizations. Lastly, the considerations relating to the close link be- 
tween the performance of companies and the satisfaction of employees could lead scholars to provide more empirical evidence regarding the variables, which more than others, are able to impact, in a decisive and effective way, on the involvement of employees in the choices regarding strategic planning.

\section{Managerial Implications}

From a managerial point of view, work can be considered instrumental to the assumption of decisions able to maximize the overall value that can be generated by the performance of local administrations.

More specifically, managers involved in the management of local communities can take advantage of an instrument capable of providing greater awareness of the possible levers to be activated to achieve a significant improvement in performance. In this regard, it is useful to underline the substantial benefit that managers would get from consulting a structured empirical analysis taking into account all the factors that the theory considers suitable to positively influence the results obtained by local administrations. This advantage is due to the opportunity offered by the work to show the performance achieved by a large sample of reference in order to make the result potentially predictable from the activation of certain levers available. This means that the administrators of local organizations, often conditioned by the limited resources available, will be able to choose which factors to influence in order to obtain the desired results, avoiding to consider those that, irrespective of what can be seen from a theoretical point of view, are not decisive in positively influencing company results. The work, in fact, shows how the adoption of appropriate strategic choices, rather than others, leads to greater involvement of social actors in the processes of generating value, improving the results. In the same way, the greater attention paid to the aspects related to sustainability, allows the public decision-makers to grasp aspects of the organizational processes otherwise neglected. As a result, this leads to higher levels of performance, leading to a broader involvement of employees, who end up feeling more and more an integral part of the local authority's mission. These benefits are then automatically transferred to the individual sphere of the employees, who will be able to take advantage of the positive effects generated by more conscious and rational choices.

\section{Conclusions}

The results of the work allow us to focus on a new and different concept of value, imbued with characters of subjectivity capable of finding adequate expression in the values possessed, in the external contingencies and in the changing conditions of the reference context.

Indeed, the variability of environmental conditions requires organizations and companies to adapt to the changing conditions of the contexts they belong to.

The ability to adapt allows the preservation of the value capable of characterizing and distinguishing the services offered. In this way, therefore, the concept 
of value tends to assert itself according to the subjective logic of each social actor, emphasizing the preferences and behavioral attitudes of the latter. The choice of a value proposition takes place, therefore, through the activation of business processes able to trigger further processes, defined as value co-creation. The latter are able, in the final analysis, to guarantee the active involvement of all the actors involved in various ways.

The set of activities, thanks to which companies and organizations in the public sector offer goods and services, are therefore only representative of a phase of the processes of value generation, which coincides with the proposition of an offer. The subsequent completion of the processes takes place, therefore, only with the confirmation by the recipients of the offer, which no longer stand only as simple actors in the process, but as figures able to contribute, in a decisive manner, to the definition of the concept of value. In fact, today's organizational methods follow a systemic logic, according to which various elements interact in a synergic manner, through the activation of functions capable of allowing the pursuit of a common purpose [60].

The systemic vision of the company had already been previously dealt with by other scholars of business administration, including Pasquale Saraceno, who was among the first in Italy to become the promoter of the systemic theory applied to the exercise of the company, emphasizing the scheme of representation of the input-output model and the feedback mechanism to the operation of the company [61].

This makes it essential to find, for all the social actors involved in the processes of value generation, resources able to allow the conservation of the value of the offer made, through the continuous adaptation to changing environmental conditions.

All this explains how the search for competitiveness is fostered by the speed with which each actor manages to incorporate the signals deriving from the other social actors, who, in turn, must also be able to perceive the changes and the signals received. Each institution, enterprise, organization, in order to be able to lengthen its survival as much as possible, must therefore begin to take on an increasingly oriented approach to collaboration. Therefore, the more we succeed in giving immediacy to the adaptation process, the more it becomes possible to achieve positions of advantage over the direct competitors, thanks to the possibility of anticipating the signals deriving from the market.

These considerations, consistent with the results of the present work, show how any system is able to last in time only through the activation of a dense network of systemic relationships and interactions.

This acknowledgment allows the local administrations to be oriented towards the assumption of choices able to put into practice the requests of the various social actors involved in the processes of value generation. In fact, the tendency to adapt their decision-making strategies to the needs of the various social actors, leads to an improvement in the performance achieved.

All this translates into the need to respond to the needs of citizens through an 
integrated action able to converge the skills of each social actor in the value proposition of a given area.

The considerations of the work seem to align with the theoretical contribution offered by some lines of research that are emerging in the study of services, which suggest orienting the actions of public and private organizations towards a wider and more synergistic sharing of knowledge, skills and resources [62]. Following this trend, therefore, the work seems to confirm the assumptions proposed by these studies [63], highlighting how governance models, based on service ecosystems, can represent the right interpretation for direct the action of local administrations towards the sustainable growth of territorial communities. However, the main limitation of the work is to contextualize the analysis in a limited territorial area, making the results not generalizable. For this reason, it could be interesting, for future research, compare the results of this work with others deriving from the application of the analysis in a different territorial area. This would make the results more generalizable.

\section{Conflicts of Interest}

The authors declare no conflicts of interest regarding the publication of this paper.

\section{References}

[1] Bernardes, E.S. (2010) The Effect of Supply Management on Aspects of Social Capital and the Impact on Performance: A Social Network Perspective. Journal of Supply Chain Management, 46, 45-55. https://doi.org/10.1111/j.1745-493X.2009.03185.x

[2] Rettab, B., Brik, A.B. and Mellahi, K. (2009) A Study of Management Perceptions of the Impact of Corporate Social Responsibility on Organisational Performance in Emerging economies: The Case of Dubai. Journal of Business Ethics, 89, 371-390. https://doi.org/10.1007/s10551-008-0005-9

[3] Tayles, M., Pike, R.H. and Sofian, S. (2007) Intellectual Capital, Management Accounting Practices and Corporate Performance: Perceptions of Managers. Accounting, Auditing \& Accountability Journal, 20, 522-548. https://doi.org/10.1108/09513570710762575

[4] Garcia-Castro, R., Ariño, M.A. and Canela, M.A. (2010) Does Social Performance Really Lead to Financial Performance? Accounting for Endogeneity. Journal of Business Ethics, 92, 107-126. https://doi.org/10.1007/s10551-009-0143-8

[5] De Groot, R.S., Alkemade, R., Braat, L., Hein, L. and Willemen, L. (2010) Challenges in Integrating the Concept of Ecosystem Services and Values in Landscape Planning, Management and Decision Making. Ecological Complexity, 7, 260-272. https://doi.org/10.1016/j.ecocom.2009.10.006

[6] Peloza, J. (2009) The Challenge of Measuring Financial Impacts from Investments in Corporate Social Performance. Journal of Management, 35, 1518-1541. https://doi.org/10.1177/0149206309335188

[7] Enticott, G. and Walker, R.M. (2005) Environmental Sustainability and Management Reform in Local Government: An Empirical Analysis. Policy \& Politics, 33, 297-322. https://doi.org/10.1332/0305573053870130 
[8] Post, J.E., Preston, L.E. and Sachs, S. (2002) Managing the Extended Enterprise: The New Stakeholder View. California Management Review, 45, 6-28. https://doi.org/10.2307/41166151

[9] Brynjolfsson, E., Hitt, L.M. and Kim, H.H. (2011) Strength in Numbers: How Does Data-Driven Decisionmaking Affect Firm Performance?

[10] Huse, M. (2008) Accountability and Creating Accountability: A Framework for Exploring Behavioural Perspectives of Corporate Governance. The Value Creating Board, Routledge, 51-72.

[11] Doty, D.H., Glick, W.H. and Huber, G.P. (1993) Fit, Equifinality, and Organizational Effectiveness: A Test of Two Configurational Theories. Academy of Management journal, 36, 1196-1250.

[12] Jusoh, R. and Parnell, J.A. (2008) Competitive Strategy and Performance Measurement in the Malaysian Context: An Exploratory Study. Management Decision, 46, 5-31. https://doi.org/10.1108/00251740810846716

[13] Aragón-Correa, J.A., Hurtado-Torres, N., Sharma, S. and García-Morales, V.J. (2008) Environmental Strategy and Performance in Small Firms: A Resource-Based Perspective. Journal of Environmental Management, 86, 88-103. https://doi.org/10.1016/j.jenvman.2006.11.022

[14] Hoque, Z. (2004) A Contingency Model of the Association between Strategy, Environmental Uncertainty and Performance Measurement: Impact on Organizational Performance. International Business Review, 13, 485-502.

https://doi.org/10.1016/j.ibusrev.2004.04.003

[15] Kalkan, A., Erdil, O. and Çetinkaya, Ö. (2011) The Relationships between Firm Size, Prospector Strategy, Architecture of Information Technology and Firm Performance. Procedia-Social and Behavioral Sciences, 24, 854-869. https://doi.org/10.1016/j.sbspro.2011.09.114

[16] Andrews, R., Boyne, G.A., Meier, K.J., O’Toole Jr., L.J. and Walker, R.M. (2005) Representative Bureaucracy, Organizational Strategy, and Public Service Performance: An Empirical Analysis of English Local Government. Journal of Public Administration Research and Theory, 15, 489-504. https://doi.org/10.1093/jopart/mui032

[17] Andrews, R., Boyne, G.A., Law, J. and Walker, R.M. (2007) Centralization, Organizational Strategy, and Public Service Performance. Journal of Public Administration Research and Theory, 19, 57-80. https://doi.org/10.1093/jopart/mum039

[18] Guan, J.C., Richard, C.M., Tang, E.P. and Lau, A.K. (2009) Innovation Strategy and Performance during Economic Transition: Evidences in Beijing, China. Research Policy, 38, 802-812. https://doi.org/10.1016/j.respol.2008.12.009

[19] Andrews, R., Boyne, G.A. and Walker, R.M. (2006) Strategy Content and Organizational Performance: An Empirical Analysis. Public Administration Review, 66, 52-63. https://doi.org/10.1111/j.1540-6210.2006.00555.x

[20] Jennings, D.F., Rajaratnam, D. and Lawrence, F.B. (2003) Strategy-Performance Relationships in Service Firms: A Test for Equifinality. Journal of Managerial Issues, 208-220.

[21] Boyne, G.A. and Walker, R.M. (2004) Strategy Content and Public Service Organizations. Journal of Public Administration Research and Theory, 14, 231-252. https://doi.org/10.1093/jopart/muh015

[22] Slater, S.F., Olson, E.M. and Hult, G.T.M. (2006) The Moderating Influence of Strategic Orientation on the Strategy Formation Capability-Performance Relationship. Strategic Management Journal, 27, 1221-1231. https://doi.org/10.1002/smj.569 
[23] Morgan, R.E. and Strong, C.A. (2003) Business Performance and Dimensions of Strategic Orientation. Journal of Business Research, 56, 163-176. https://doi.org/10.1016/S0148-2963(01)00218-1

[24] Luo, Y. and Park, S.H. (2001) Strategic Alignment and Performance of MarketSeeking MNCs in China. Strategic Management Journal, 22, 141-155. https://doi.org/10.1002/1097-0266(200101)22:2<141::AID-SMJ151>3.0.CO;2-O

[25] Cherian, J. and Jacob, J. (2013) Impact of Self Efficacy on Motivation and Performance of Employees. International Journal of Business and Management, 8, 80. https://doi.org/10.5539/ijbm.v8n14p80

[26] Manzoor, Q.A. (2012) Impact of Employee Motivation on Organizational Effectiveness. Business Management and Strategy, 3, 1.

[27] Bright, L. (2007) Does Person-Organization Fit Mediate the Relationship between Public Service Motivation and the Job Performance of Public Employees? Review of Public Personnel Administration, 27, 361-379. https://doi.org/10.1177/0734371X07307149

[28] Vickers, I., James, P., Smallbone, D. and Baldock, R. (2005) Understanding Small Firm Responses to Regulation: The Case of Workplace Health and Safety. Policy Studies, 26, 149-169. https://doi.org/10.1080/01442870500127626

[29] Leisink, P. and Steijn, B. (2009) Public Service Motivation and Job Performance of Public Sector Employees in the Netherlands. International Review of Administrative Sciences, 75, 35-52. https://doi.org/10.1177/0020852308099505

[30] Linnenluecke, M.K. and Griffiths, A. (2010) Corporate Sustainability and Organizational Culture. Journal of World Business, 45, 357-366. https://doi.org/10.1016/j.jwb.2009.08.006

[31] Jabbour, C.J.C. and Santos, F.C.A. (2008) The Central Role of Human Resource Management in the Search for Sustainable Organizations. The International Journal of Human Resource Management, 19, 2133-2154. https://doi.org/10.1080/09585190802479389

[32] Menguc, B. and Ozanne, L.K. (2005) Challenges of the "Green Imperative": A Natural Resource-Based Approach to the Environmental Orientation-Business Performance Relationship. Journal of Business research, 58, 430-438. https://doi.org/10.1016/j.jbusres.2003.09.002

[33] Zhu, Q., Sarkis, J. and Lai, K.H. (2008) Confirmation of a Measurement Model for Green Supply Chain Management Practices Implementation. International Journal of Production Economics, 111, 261-273. https://doi.org/10.1016/j.ijpe.2006.11.029

[34] Min, H. and Galle, W.P. (2001) Green Purchasing Practices of US Firms. International Journal of Operations \& Production Management, 21, 1222-1238. https://doi.org/10.1108/EUM0000000005923

[35] Zhu, Q. and Geng, Y. (2001) Integrating Environmental Issues into Supplier Selection and Management. Greener Management International, 35, 27-40. https://doi.org/10.9774/GLEAF.3062.2001.au.00005

[36] Zhu, Q. and Sarkis, J. (2004) Relationships between Operational Practices and Performance among Early Adopters of Green Supply Chain Management Practices in Chinese Manufacturing Enterprises. Journal of Operations Management, 22, 265-289. https://doi.org/10.1016/j.jom.2004.01.005

[37] Burton, C.H. and Turner, C. (2003) Manure Management: Treatment Strategies for Sustainable Agriculture. Editions Quae.

[38] Boyne, G.A. and Walker, R.M. (2010) Strategic Management and Public Service 
Performance: The Way Ahead. Public Administration Review, 70, s185-s192. https://doi.org/10.1111/j.1540-6210.2010.02271.x

[39] Bansal, P. (2005) Evolving Sustainably: A Longitudinal Study of Corporate Sustainable Development. Strategic Management Journal, 26, 197-218.

https://doi.org/10.1002/smj.441

[40] Van Breukelen, W., Van der Vlist, R. and Steensma, H. (2004) Voluntary Employee Turnover: Combining Variables from the "Traditional" Turnover Literature with the Theory of Planned Behavior. Journal of Organizational Behavior, 25, 893-914. https://doi.org/10.1002/job.281

[41] Porter, L.W., Steers, R.M., Mowday, R.T. and Boulian, P.V. (1974) Organizational Commitment, Job Satisfaction, and Turnover among Psychiatric Technicians. Journal of Applied Psychology, 59, 603. https://doi.org/10.1037/h0037335

[42] Bastian, V.A., Burns, N.R. and Nettelbeck, T. (2005) Emotional Intelligence Predicts Life Skills, But Not as well as Personality and Cognitive Abilities. Personality and Individual Differences, 39, 1135-1145. https://doi.org/10.1016/j.paid.2005.04.006

[43] Churchill Jr., G.A. (1979) A Paradigm for Developing Better Measures of Marketing Constructs. Journal of Marketing Research, 16, 64-73. https://doi.org/10.1177/002224377901600110

[44] Jolliffe, I.T. (2002) Graphical Representation of Data Using Principal Components. In: Manel, S., Williams, H.C., et al., Eds., Principal Component Analysis, Springer, New York, 78-110.

[45] Hair, H.J. (2005) Outcomes for Children and Adolescents after Residential Treatment: A Review of Research from 1993 to 2003. Journal of Child and Family Studies, 14, 551-575. https://doi.org/10.1007/s10826-005-7188-9

[46] Tabachnick, B.G. and Fidell, L.S. (2007) Using Multivariate Statistics. Allyn \& Bacon/Pearson Education.

[47] Pett, M.A., Lackey, N.R. and Sullivan, J.J. (2003) Making Sense of Factor Analysis: The Use of Factor Analysis for Instrument Development in Health Care Research. Sage, Newcastle upon Tyne.

[48] Capelli, R., Toffanin, S., Generali, G., Usta, H., Facchetti, A. and Muccini, M. (2010) Organic Light-Emitting Transistors with an Efficiency That Outperforms the Equivalent Light-Emitting Diodes. Nature Materials, 9, 496. https://doi.org/10.1038/nmat2751

[49] Hu, L.T. and Bentler, P.M. (1998) Fit Indices in Covariance Structure Modeling: Sensitivity to Underparameterized Model Misspecification. Psychological Methods, 3, 424. https://doi.org/10.1037/1082-989X.3.4.424

[50] Netemeyer, R., Bentler, P., Bagozzi, R., Cudeck, R., Cote, J., Lehmann, D. and Ambler, T. (2001) Structural Equations Modeling.

[51] Perrini, F. and Tencati, A. (2006) Sustainability and Stakeholder Management: The Need for New Corporate Performance Evaluation and Reporting Systems. Business Strategy and the Environment, 15, 296-308. https://doi.org/10.1002/bse.538

[52] Olson, E.M., Slater, S.F. and Hult, G.T.M. (2005) The Performance Implications of Fit among Business Strategy, Marketing Organization Structure, and Strategic Behavior. Journal of Marketing, 69, 49-65. https://doi.org/10.1509/jmkg.69.3.49.66362

[53] Ali, I., Rehman, K.U., Ali, S.I., Yousaf, J. and Zia, M. (2010) Corporate Social Responsibility Influences, Employee Commitment and Organizational Performance. African Journal of Business Management, 4, 2796-2801. 
[54] Nilsson, L., Carlsson, J., Danielsson, A., Fugl-Meyer, A., Hellström, K., Kristensen, L. and Grimby, G. (2001) Walking Training of Patients with Hemiparesis at an Early Stage after Stroke: A Comparison of Walking Training on a Treadmill with Body Weight Support and Walking Training on the Ground. Clinical Rehabilitation, 15, 515-527. https://doi.org/10.1191/026921501680425234

[55] Buck, J.M. and Watson, J.L. (2002) Retaining Staff Employees: The Relationship between Human Resources Management Strategies and Organizational Commitment. Innovative Higher Education, 26, 175-193.

https://doi.org/10.1023/A:1017916922194

[56] Bakker, A.B. and Schaufeli, W.B. (2008) Positive Organizational Behavior: Engaged Employees in Flourishing Organizations. Journal of Organizational Behavior. The International Journal of Industrial, Occupational and Organizational Psychology and Behavior, 29, 147-154. https://doi.org/10.1002/job.515

[57] Kuvaas, B. (2006) Performance Appraisal Satisfaction and Employee Outcomes: Mediating and Moderating Roles of Work Motivation. The International Journal of Human Resource Management, 17, 504-522. https://doi.org/10.1080/09585190500521581

[58] Sharabati, A.A.A., Naji Jawad, S. and Bontis, N. (2010) Intellectual Capital and Business Performance in the Pharmaceutical Sector of Jordan. Management Decision, 48, 105-131. https://doi.org/10.1108/00251741011014481

[59] Antonelli, V., Boyns, T. and Cerbioni, F. (2006) Multiple Origins of Accounting? An Early Italian Example of the Development of Accounting for Managerial Purposes. European Accounting Review, 15, 367-401. https://doi.org/10.1080/09638180600916275

[60] Golinelli, G.M. (2013) L'approccio sistemico vitale: Nuovi orizzonti di ricerca per il governo dell'impresa. Sinergie Italian Journal of Management, 80.

[61] Antonelli, V. (2018) Accumulazione ed eterodossia nell'economia aziendale classica. Pasquale Saraceno e i fondamenti della disciplina. Rirea Storica, Napoli.

[62] Loia, V., Maione, G., Tommasetti, A., Torre, C., Troisi, O. and Botti, A. (2016) Toward Smart Value Co-Education. In: Smart Education and e-Learning 2016, Springer, Cham, 61-71. https://doi.org/10.1007/978-3-319-39690-3_6

[63] Ciasullo, M.V., Maione, G., Torre, C. and Troisi, O. (2017) The Growth of Carpooling: Insights from a Social Media Investigation. Toulon-Verona Conference "Excellence in Services". 